\title{
S. Harrison Thomson
}

The international conference on "The Nationality Problem in the Nineteenth Century Habsburg Monarchy: a Critical Reappraisal," held at Indiana University on April 2-6, 1966, and the volume of the Yearbook in which the contributions to that conference were published were both dedicated to "Hans Kohn, Arthur J. May, and S. Harrison Thomson, three distinguished pioneer American scholars of Habsburg history who, through their scholarship and leadership, inspired so many others to devote themselves to a study of the field." All three of these scholars served at one time or another as chairman of the Conference Group for Central Europe, and one of them, S. Harrison Thomson, was one of the four historians who founded the Conference Group in December, 1957. All three were good teachers who trained some of the most able of this generation's scholars in Central European history. All three had a vast breadth of knowledge and vision and also produced major works in a number of fields other than the history of the Habsburg monarchy, and their efforts left a profound imprint on subsequent scholarship. All three once served as invaluable members of the editorial boards of the Austrian History Yearbook and its predecessor, the Austrian History News Letter.

The first of these "pioneer scholars" to die was Arthur J. May, who passed away on June 17, 1968. Hans Kohn died on March 16, 1971, and S. Harrison Thomson, on November 19, 1975. The death of these three scholars marks the end of a significant era in the development of Central European scholarship on the North American continent.

Robert J. Kerner and Robert $\mathrm{H}$. Lord, both of whom were trained at Harvard by Archibald Cary Coolidge, were the first two graduate students in the United States specializing in East European history. S. Harrison Thomson, who was born in Pasadena, California, on November 5, 1895, received his advanced historical training at Oxford University and at Charles University in Prague and was the third wellprepared American scholar in East-Central European history.

Between 1941 and 1964 the Journal of Central European Affairs, which he founded to serve as an outlet for the research of scholars whose accustomed channels of communication were interrupted by the war, was the main vehicle in the United States and Canada for scholarly publication in the Central and East-Central European field. More than any other scholarly enterprise, the Journal stimulated an increasing number of well-trained, serious students to devote their energies to the then relatively new fields of Central, East-Central, and Southeastern European history. 
Not only did Thomson edit the Journal of Central European Affairs between 1941 and 1964 but he also edited Progress of Medieval Studies in the United States and Canada and Medievalia et Humanistica. He performed these heavy editorial chores, with the assistance of a single secretary, while teaching full time at the University of Colorado. During the same period he also served on the editorial board of The American Slavic and East European Review (now Slavic Review) and wrote a large number of articles and reviews and several books which were major contributions to medieval and East-Central European history. Among his works in the latter field were Magistri Johannis Hus Tractuatus Responsivus; Magistri Johannis Hus Tractuatus de Ecclesia; and Czechoslovakia in European History, for which he was awarded the Czechoslovakian Prize for Literature. He also collected one of the finest private libraries in America in medieval and EastCentral European history. The collection is now housed in the Sterling Memorial Library of Yale University.

Equally important were Thomson's contributions as a teacher at the California Institute of Technology (1929-1931), the University of Chicago (1934-1935), Carleton College (1935-1936), Indiana University (1950-1951), the University of Washington (1964-1965), the University of California at Los Angeles (1965-1966), and the University of Colorado, where he taught from 1936 until his retirement in 1964. His graduate students found him to be an exacting taskmaster. He insisted that they master several Slavic languages and that they make a rigorous investigation of original sources before beginning their writing. At the same time, he won their devotion by going out of his way to assist them, both in their work as students and in their subsequent professional careers. Several of his former students have earned national reputations.

Thomson was accorded international recognition for his work in both the medieval and East-Central European fields. His volume on Latin Book Hands of the Later Middle Ages won the Hoskins medal of the Medieval Academy of America. He was a fellow and first vice-president of the Medieval Academy of America (1959-1962) and a councillor of the History of Science Society (1947-1953). Largely for his contributions to East-Central European history, he was elected corresponding fellow of the Polish Academy of Sciences (Cracow) in 1947; honorary fellow of the Czech Academy of Arts and Sciences in 1948; and corresponding fellow of the Polish Academy of Arts and Letters (London) in 1961. In 1973 he received the Award for Distinguished Contributions to Slavic Studies from the American Association for the Advancement of Slavic Studies.

R. J. R. 